\title{
Mapping landscape-scale peatland degradation using airborne lidar and multispectral data
}

\author{
Donna Carless $(\mathbb{D} \cdot$ David J. Luscombe • Naomi Gatis • Karen Anderson • \\ Richard E. Brazier
}

Received: 28 September 2018/Accepted: 27 May 2019/Published online: 12 June 2019

(C) The Author(s) 2019

\begin{abstract}
Context An increased interest in the restoration of peatlands for delivering multiple benefits requires a greater understanding of the extent and location of natural and artificial features that contribute to degradation.

Objectives We assessed the utility of multiple, finegrained remote sensing datasets for mapping peatland features and associated degraded areas at a landscapescale. Specifically, we developed an integrated approach to identify and quantify multiple types of peatland degradation including: anthropogenic drainage ditches and peat cuttings; erosional gullies and bare peat areas.

Methods Airborne LiDAR, CASI and aerial image datasets of the South West UK, were combined to identify features within Dartmoor National Park peatland area that contribute to degradation. These features were digitised and quantified using ArcGIS before appropriate buffers were applied to estimate the wider ecohydrologically affected area.
\end{abstract}

D. Carless $(\bowtie) \cdot$ D. J. Luscombe · N. Gatis .

R. E. Brazier

Department of Geography, College of Life and

Environmental Sciences, University of Exeter, Exeter,

Devon EX4 4RG, UK

e-mail: d.carless@exeter.ac.uk

\section{K. Anderson}

Environment and Sustainability Institute, University of Exeter, Penryn Campus, Penryn, Cornwall TR10 9FE, UK
Results Using fine-scale, large-extent remotely sensed data, combined with aerial imagery enabled key features within the wider expanse of peatland to be successfully identified and mapped at a resolution appropriate to future targeted restoration. Combining multiple datasets increased our understanding of spatial distribution and connectivity within the landscape. An area of $29 \mathrm{~km}^{2}$ or $9.2 \%$ of the Dartmoor peatland area was identified as significantly and directly ecohydrologically degraded.

Conclusions Using a combination of fine-grained remotely sensed datasets has advantages over traditional ground survey methods for identification and mapping of anthropogenic and natural erosion features at a landscape scale. The method is accurate, robust and cost-effective particularly given the remote locations and large extent of these landscapes, facilitating effective and targeted restoration planning, management and monitoring.

Keywords Peatlands - LiDAR - Remote sensing · GIS · Landscape-scale $\cdot$ Peatland degradation

\section{Introduction}

Peatland ecosystems are vulnerable, both to climate change and anthropogenic activities (drainage, conversion for agriculture, burning and extraction for fuel and horticulture) (Gorham 1991; Joosten and Clarke 
2002; Bain et al. 2011) and only 10-12\% of the global peatland resource remains undamaged (International Peatland Society 2008).

Recently, blanket peatlands, which represent the largest expanse of semi-natural habitat in the UK (Littlewood et al. 2010), have been recognised for the wide range of ecosystem services that they provide including; climate change mitigation, carbon sequestration/storage, runoff regulation and improvement of water quality, and the provision of a landscape with recreational and cultural value (Joosten and Clarke 2002; Kimmel and Mander 2010; Bain et al. 2011; Grand-Clement et al. 2013). Accordingly, there is increasing interest in peatland restoration (rewetting) to safeguard these multiple benefits. However, this awareness has highlighted the need for a greater understanding of the extent and location of peatland features, both natural and artificial, particularly where peatlands have experienced significant disturbance.

Restoration and management of peatlands requires an understanding of peatland structure at the spatial scales at which peatlands function. For example, it is now widely understood that, in addition to controls such as topography and peat type, artificial peatland drainage and associated erosional gullies promote localised drainage and are the biggest cause of water table change, resulting in long term impacts on peatland hydrology and ecological structure and function (e.g. initiating changes in hydrological connectivity, carbon cycling, species composition and microform patterns) (Evans and Lindsay 2010; Luscombe et al. 2016; Minayeva et al. 2017). Even historical, partially re-vegetated drains continue to act as artificial flow paths due to localised changes in topography as a result of long-term subsidence of the peat surface adjacent to the drainage ditches (Haapalehto et al. 2011, 2014; Holden et al. 2011).

The recent focus on landscape-scale conservation management has reinforced the need for landscape scale mapping and monitoring, a task that is challenging to deliver using traditional ground-based methods (Cole et al. 2013). Landscape-scale mapping approaches allow the identification of both vulnerable (degraded) peatland areas as well as intact, functioning areas which may be at risk due to their proximity to degraded zones or drainage features (Minayeva et al. 2017). In addition, identifying functioning peatland areas can provide information to inform realistic and spatially explicit restoration goals, in addition to identifying where such pristine peatlands may still exist.

The current condition of climatically-marginal peat landscapes such as those found on Dartmoor in the South West of England, are poorly characterised, limiting understanding of where restoration/management efforts should focus. Furthermore, restoration practices such as ditch blocking are costly and require extensive partnership funding and cooperation (Holden et al. 2008; Bonn et al. 2016). Bain et al. (2011) have therefore, encouraged mapping of peatland ecosystems at the catchment scale to better manage this effort. Detailed spatial assessments of the distribution of features causing degradation (e.g. drainage ditches), as well as a broader condition assessment help to ensure that restoration works are efficient, economical and cost effective (Moxey and Moran 2014; Aitkenhead et al. 2016).

However, the review by Li et al. (2018), highlights that the knowledge needed to underpin restoration management must also extend to the fine-scale or microtope (in sensu Lindsay (2010)) to assess fully the changes in peatland structure and function. Mapping of natural erosion features and assessment of artificial, linear drainage features must therefore be completed at the-sub metre scale (Connolly and Holden 2017) as well as across landscape extents. Despite this, and likely due to the fact that until recently there was a lack of freely accessible data, comprehensive, fine-scale regional peatland mapping studies are still rare (see Milton et al. 2005; Yallop et al. 2006; Keyworth et al. 2009; Evans and Lindsay 2010; Medcalf et al. 2014 for notable exceptions across national scales) and to date, limited high resolution mapping of the key peatland features that contribute to peatland degradation have been completed at the landscape-scale.

Existing resources of peatland extent and condition are also often based on data that are no longer applicable due to their age, their coarse spatial resolution or the methods used (i.e., inventories that were completed in the 1970s-1990s, National/Regional scale mapping studies and studies based on literature review and 'expert' opinion rather than physical data). This may be explained by the fact that traditional survey and assessment methods, e.g. ground based field surveys (Burton 1987) and plot or transect-scale vegetation assessments (Poulin et al. 2013; Rochefort et al. 2013), are time consuming and costly over large extents (Mehner et al. 2004; Li and 
Chen 2005). In addition, the subjective nature of field data acquisition and uncertainties associated with plot surveys (different observers and different times of the year) means that systematic bias can be introduced (Carlsson et al. 2005) and a large number of plots are needed in sites with a high level of small scale variability so that features are not underestimated (Bonnett et al. 2011).

Remote sensing and GIS are however, becoming more widely used as advanced tools for landscapescale investigations (Evans and Lindsay 2010; Luscombe et al. 2015a, b, 2016). Furthermore, with the increasing open-access availability of remotely sensed, fine-scale data covering large extents (including Light Detection and Ranging - LiDAR, Multi- and Hyperspectral aerial and multi-annual, visible aerial photography) which are robust and repeatable, landscape-scale mapping approaches are now becoming deliverable.

Automated methods for detecting and mapping erosional gullies are also being developed using such data, at sub-catchment/hillslope extents (Evans and Lindsay 2010; Shruthi et al. 2011; Höfle et al. 2013). These methods enable quantification of features and provide a means of understanding their spatial distribution and connectivity within the landscape, thus facilitating effective and targeted restoration planning, management and monitoring (Aitkenhead et al. 2016; Gatis et al. 2019).

The aim of this study was to assess the utility of fine-grained remote sensing data for mapping both natural and anthropogenic peatland features. Specific objectives were to develop an integrated approach which could identify and quantify multiple types of peatland degradation across the moorland extent of Dartmoor National Park, including: 1. Anthropogenic drainage ditches and peat cuttings, 2. Erosional gullies and 3. Bare peat areas.

\section{Methods}

\section{Study system}

The area of interest for this study was located within the primary moorland extent of the Dartmoor National Park, located in southwest England (Fig. 1). Dartmoor contains the largest expanse of upland blanket bog in the south of England $\left[315 \mathrm{~km}^{2}\right.$ of the $945 \mathrm{~km}^{2}$ national park area is mapped as peat (Gatis et al. 2019)]. The peat deposits on Dartmoor are estimated to extend to depths greater than $7 \mathrm{~m}$ (Fyfe and Greeves 2010; Newman 2010; Parry et al. 2012; Fyfe et al. 2014) and overlie predominantly granitic bedrock (Gatis et al. 2019). Dartmoor's blanket bog ecosystems are the primary reason for the designation of Dartmoor's Special Area of Conservation (SAC). However, much of Dartmoor's peatland has been affected by past human activity, specifically drainage for agricultural improvement (during the 19th and 20th centuries), domestic peat-cutting (since the 18th century) and commercial extraction (since the late 19th century), burning (swaling), and military activity (Grand-Clement et al. 2015). These activities are known to have affected the ecohydrological structure and function, evidenced by widespread erosion, carbon loss and ecosystem degradation (Daniels et al. 2008; Luscombe et al. 2015b; Gatis et al. 2016).

In addition, concern has been raised over the longterm resilience of Dartmoor's peatland ecosystem to climate change. Gallego-Sala et al. (2010) predict that by 2080 , Dartmoor and other south west UK peatlands will no longer support peat formation, due to warmer climates. Therefore, the ability of these climaticallymarginal, yet spatially extensive peatlands to provide key ecosystem services in an already degraded condition may be limited. Consequently, pilot blanket bog restoration initiatives have taken place through the Dartmoor Mires Project from 2010 to 2015 (South West Water 2014; Bowers 2015). Restoration activities have been targeted at the rewetting of areas identified as drained or ecologically degraded by the expansion of bare peat "pans". This work has prioritised the blocking of active gully features, aiming to promote vegetation re-growth and ultimately restart peat accumulation as demonstrated elsewhere (Gorham and Rochefort 2003; Bain et al. 2011). However, strategic decision-making informed by a whole landscape-scale understanding of peatland degradation has not hitherto been possible.

Dartmoor was also chosen as a study landscape as it is already a test bed for monitoring and evaluation of restoration activities and current peatland condition. Furthermore, LiDAR data covering the whole of the study area were freely available for download (for research purposes), following the Natural Environment Research Council (NERC) survey by the Tellus 


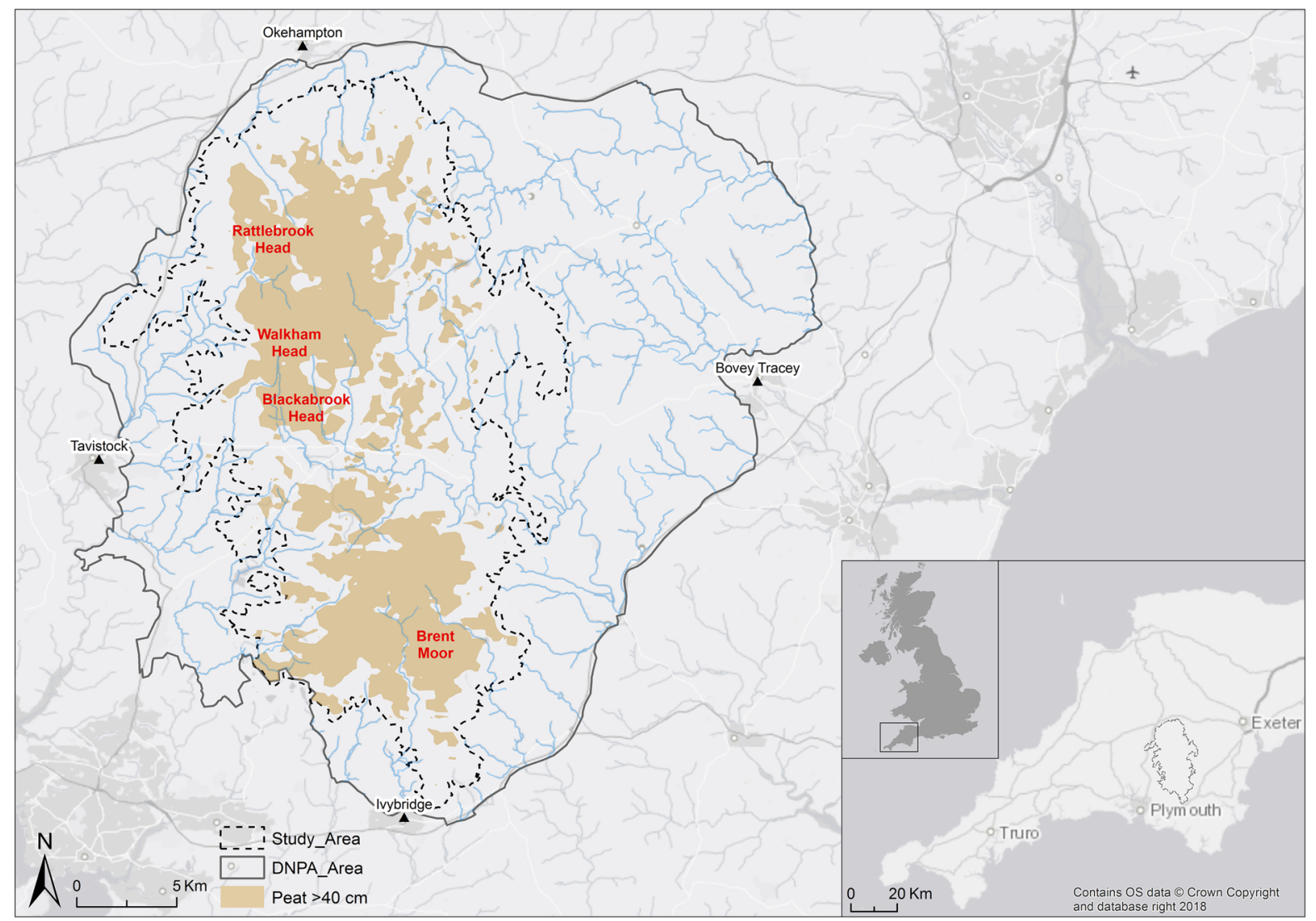

Fig. 1 Map illustrating the study area (dashed line) within the Dartmoor National Park (solid grey line) and their location within the south west region and UK (inset maps). Areas of deep

aircraft in 2013 (further detail is available from www. tellusgb.ac.uk and Gatis et al. (2019)).

\section{Remote sensing data}

Our approach employed airborne LiDAR, CASI (Compact Airborne Spectrographic Imager), and aerial image datasets.

LiDAR data were collected during the NERC TellusSW project in the summer and autumn of 2013 (www.tellusgb.ac.uk). The raw LiDAR dataset was processed to create a digital surface model (DSM) at a spatial resolution of $1 \mathrm{~m}$ and $2 \mathrm{~cm}$ vertical resolution. These data were downloaded from https://catalogue. ceh.ac.uk/documents/b81071f2-85b3-4e31-8506-cabe 899f989a (Ferraccioli et al. 2014).

CASI (visible and near infrared) hyperspectral image data were also available for the site from an earlier survey by the Environment Agency Geomatics peat $(>40 \mathrm{~cm})$ are shown by brown shading. Red text labels name the main historical, industrial peat cutting areas

Group in 2009. CASI hyperspectral imagery provides 19 bands of visible and near infrared hyperspectral imagery ranging between 365 and $1050 \mathrm{~nm}$. In addition, red, green, blue aerial photography (RGB) (0.125 $\mathrm{m}$ resolution) and colour and near infrared aerial photography (CNIR) datasets of the region, from flights spanning several years (including 2010 and 2015), were provided by Dartmoor National Park Authority (DNPA).

\section{Peatland feature mapping}

A low-pass moving window $(11 \times 11$ cell $)$ average filter was applied to the original DSM to provide a smoothed model. This smoothed version was then subtracted from the original DSM and the residual topography used to derive a "de-trended" dataset. A de-trended LiDAR DSM product was needed in order to examine the high frequency micro-topographic 
landforms, independent of the surrounding landscape structure.

Mapping drainage ditches and peat cuttings

Using knowledge of the history of peat cutting on Dartmoor (Newman 2010) and of the deep peat areas (Gatis et al. 2019) (Fig. 1) to contextualise features, a set of criteria was established and a process for visual assessment and classification of features such as drainage ditches and peat cuttings developed (Fig. 2).

Anthropogenic drainage ditches and peat cuttings were manually identified in the de-trended LiDAR DSM. Linear depressions and negative topography could be discriminated by visual interpretation of the LiDAR images. Each $1 \mathrm{~km}$ grid square was visually assessed in turn, in combination with the CNIR and RGB aerial imagery. Different representations of the aerial imagery data (CNIR and RGB datasets) were found to enhance the features for example, true colour [red (1), green (2) and blue (3)] and false colour [near infra-red (1), red (2) and green (3)]. Identified features were then digitised as polylines (drains) or polygons (cuttings) in ArcGIS (ESRI 2015. ArcMap 10.3.1. Redlands, CA). This allowed for the production of a series of digitised layers each showing a different 'disturbance' feature (e.g. drainage ditch or peat cutting) and therefore mapping of their extent and location. In addition, attributes were assigned to individual features to provide further classification. For example, peat cuttings were classified as individual, distinct, well-defined features-likely to be

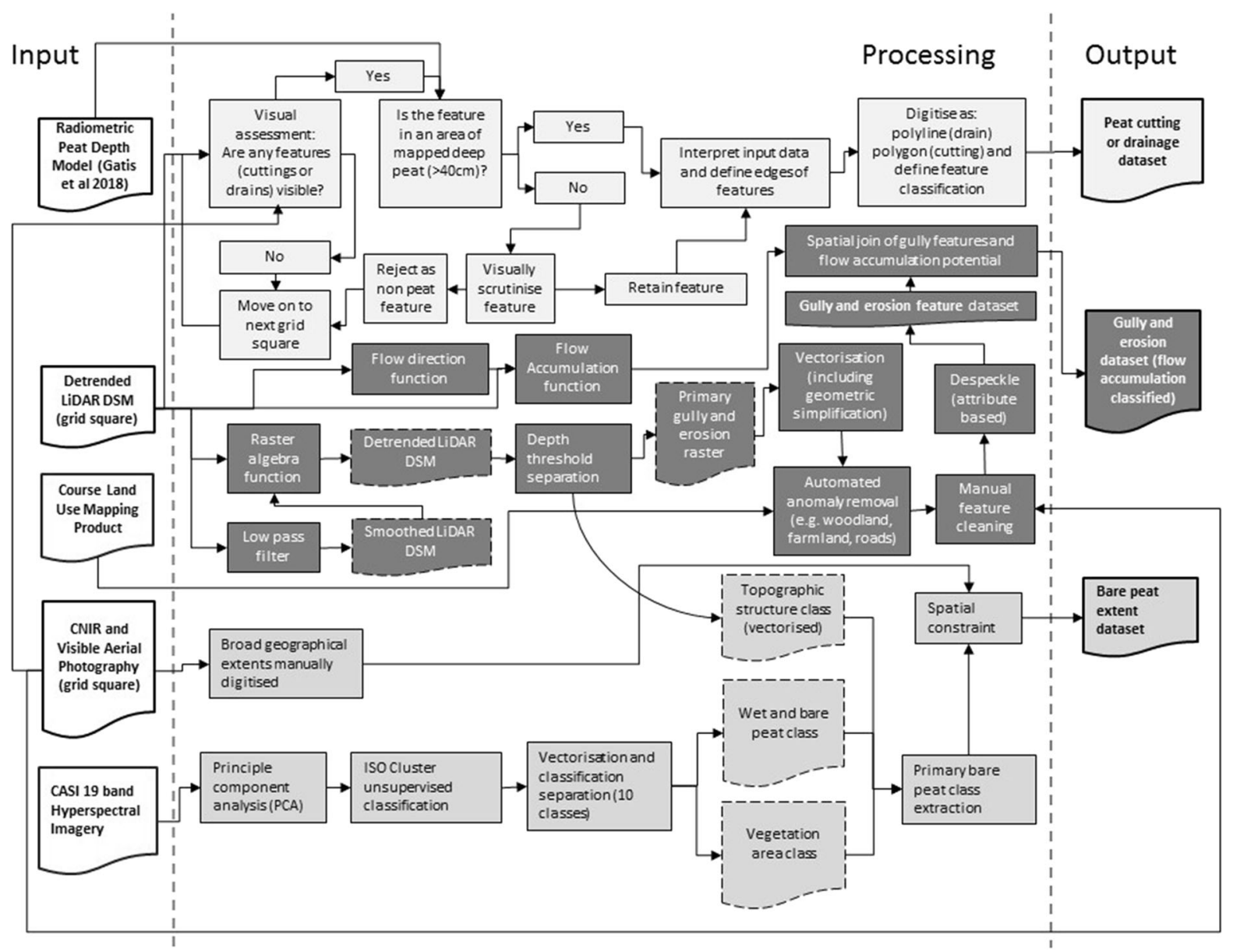

Fig. 2 Flow diagram showing processing chain for digitising and classifying (1) Anthropogenic drainage ditch and peat cutting features, (2) Gully and erosion features and (3) Bare peat, using LiDAR and aerial imagery. Left hand boxes show input datasets. Right hand boxes show resultant output datasets. (Color figure online) 
related to small-scale domestic peat cutting activity or as larger, commercial peat 'setts' where large areas of drainage and peat extraction were evidenced.

\section{Mapping erosional gullies}

De-trended data derived from the LiDAR DSM were used to identify the location of micro-topographic depressions below a threshold appropriate to the known size of measured gully features (Depth threshold separation, Fig. 2). The results were further checked against aerial photography datasets to ensure appropriate representation of the output features. The two dimensional geometry of the features was also used to ensure small extents of erroneous data were discarded $\left(<38.7 \mathrm{~m}^{2}\right)$ (Attribute based despeckle, Fig. 2). Additionally, the resultant data were manually cleaned by the visual inspection of each $1 \mathrm{~km}$ grid square and removal of natural and anthropogenic features not characteristic of erosion features but that had similar morphological traits. For example, roads, footpaths or tracks; features identified as rivers or water bodies from Ordnance Survey mapping and features located in areas outside of land-cover classes known to support such erosional features (Automated anomaly removal and Manual feature cleaning, Fig. 2).

The resultant data were then processed to derive those mapped features most likely to be functioning as morphologically active (i.e. eroding) gully features. A simple flow accumulation model (Evans et al. 2005; Luscombe et al. 2015a), (a method which calculates theoretical surface flow accumulated in each DSM cell), generated from the parent LiDAR DSM was spatially joined to the attribute table of the mapped gully data to estimate the potential of each feature to accumulate surface flow and therefore be actively impacted by surface water erosion (Spatial join of gully features and flow accumulation potential, Fig. 2).

The flow accumulation analysis is a conceptual oversimplification as it assumes that all rainfall is converted to runoff in the landscape. However, as peatlands may be subject to frequent saturation excess overland flow (Luscombe et al. 2015a), the approach is justified as a computationally efficient way of estimating whether features that appear to be derived from surface/near surface water erosion also coincide with areas in the landscape where energetic surface water runoff is likely to be generated. These data enabled mapped features which may accumulate flow the most, to be numerically identified via appended attribute data and statistically separated into (conceptually) the most and least potentially morphologically active. The resultant data included all the mapped (cleaned) gully features as well as an attribute classification of high, medium and low erosional potential (based on standard deviation of the data distribution), at the request of the data users.

Mapping bare and sparsely vegetated peat areas

The CASI data were used in conjunction with structural data from the de-trended LiDAR datasets at $1 \mathrm{~m}^{2}$ resolution, to map the position of bare and sparsely vegetated peat areas. Hyperspectral CASI data were pre-processed using principle component analysis (PCA), in line with Rodarmel and Shan (2002) to ensure that the information content from the 19 CASI bands which best represented the land surface variability were able to be included in the subsequent classification implementation. These data were included in an ISODATA unsupervised clustering approach (Iterative Self-Organizing Data Analysis Technique), and 10 classes were identified. From these 10 parent classes, 2 sub-groups were extracted describing the position of the wet and bare peat "pans" and the vegetated areas surrounding them (Fig. 2). This classification dataset was further constrained using the topographic depressions isolated from the LiDAR DSM to restrict the bare peat area extracted (Fig. 2). Given that bare peat features are formed from the loss of peat soil/vegetation, bare peat areas are topographically lower than proximal areas that exhibit vegetation cover and can therefore aid the extraction of individual features from spectrally classified extents (Gatis et al. 2016). Finally, aerial image data (CNIR and RGB) were evaluated to spatially constrain the overall extent of the output datasets from the CASI and DSM data analysis. Similarly to the mapping of gully features, this last step ensured that any anomalous but spectrally/structurally similar features that occurred outside dendritic erosion networks were not included. 
Modelling the extent of ecohydrological damage

For the purpose of management and restoration planning it is important to identify the total ecohydrologically affected extent (i.e. where the water table is permanently below the vegetated surface and peat forming vegetation cannot persist). The impact of drainage features is not restricted to the immediate margins of the feature. Peatland drains modify and lower the water table for some distance beyond it (Lindsay et al. 2014). Whilst the zone of drawdown varies depending on many things such as slope, peat type, drain width and orientation (Luscombe et al. 2016), there are a number of generally agreed principles. Primarily water table drawdown occurs asymmetrically for drain features that are contoured and run across slope (Holden et al. 2006; Labadz et al. 2010; Luscombe et al. 2016) but more symmetrically for drains orientated up-/downslope. Other peatland features such as peat cuttings and erosional gullies may be assumed to behave in a similar way to drains with regards to water table drawdown in adjacent peat. However, for computational simplicity it was assumed that drawdown is equal around the perimeter of these features.

In an extended analysis, cross-slope drains were identified using a model of hillslope position generated for each feature using LiDAR DSM data. A $3 \mathrm{~m}$ buffer was then applied only to the downslope side of these drains (see Table 1) to estimate the asymmetric water table drawdown in the proximal area. For all other non-cross slope drain features a $3 \mathrm{~m}$ buffer (see Table 1), was applied to the whole perimeter to characterise the total area of ecohydrological change (with the drains themselves assumed to have a width of $0.5 \mathrm{~m}$ ) (Fig. 4).

In addition, a subset of features previously identified as peat cuttings (specifically those classified as discrete and well-defined as these were known to have distinct edges) were selected to have $3 \mathrm{~m}$ buffers applied to their perimeter (see Table 1), to identify the wider area likely to be ecohydrologically impacted by those features (Fig. 4).

Identification of the wider ecohydrological impact that erosion and gully features have was completed using the flow accumulation modelling from the LiDAR DSM. Attributes generated for individual erosion and gully features enabled the automatic statistical separation (using standard deviation) of features that accumulate the most flow and may, therefore, be the most vulnerable to future episodic soil erosion. This subset of active gullies (classified as having "medium" and "high" flow) were subsequently buffered by $3 \mathrm{~m}$ around their perimeter (see Table 1 and Fig. 4). Finally, bare peat areas were buffered by $2.5 \mathrm{~m}$ around their perimeter (Table 1).

Table 1 A summary of buffer sizes used to represent the areas of ecohydrological change relating to each mapped feature, the assumptions used and the literature consulted

\begin{tabular}{|c|c|c|c|}
\hline $\begin{array}{l}\text { Mapped } \\
\text { feature }\end{array}$ & Buffer size & Assumption & Source \\
\hline $\begin{array}{r}\text { Drainage } \\
\text { ditches }\end{array}$ & $\begin{array}{l}3 \text { m (Asymmetric } \\
\text { dependant on } \\
\text { hillslope position) }\end{array}$ & $\begin{array}{l}\text { Water table drawdown occurs asymmetrically for drain } \\
\text { features that are contoured and run across slope up to a } \\
\text { distance of } 3 \mathrm{~m} \text { on the downslope side and assumed } \\
\text { symmetrical for non-cross slope drains }\end{array}$ & $\begin{array}{l}\text { Holden et al. } 2006 \\
\text { Labadz et al. } 2010 \\
\text { Luscombe et al. } 2016 \\
\text { Exmoor monitoring, } \\
\text { University of Exeter }\end{array}$ \\
\hline $\begin{array}{l}\text { Peat } \\
\text { cuttings }\end{array}$ & $3 \mathrm{~m}$ & $\begin{array}{l}\text { Water table drawdown occurs symmetrically up to a distance } \\
\text { of } 3 \mathrm{~m} \text { around the perimeter of discrete peat cuttings }\end{array}$ & $\begin{array}{l}\text { Holden et al. 2006; Labadz } \\
\text { et al. 2010; Luscombe } \\
\text { et al. } 2016\end{array}$ \\
\hline $\begin{array}{l}\text { Erosion and } \\
\text { gully } \\
\text { features }\end{array}$ & $3 \mathrm{~m}$ & $\begin{array}{l}\text { Water table drawdown occurs symmetrically up to a distance } \\
\text { of } 3 \mathrm{~m} \text { from the edge of gully and erosion features }\end{array}$ & $\begin{array}{l}\text { Holden et al. 2006; Labadz } \\
\text { et al. 2010; Luscombe } \\
\text { et al. } 2016\end{array}$ \\
\hline Bare peat & $2.5 \mathrm{~m}$ & $\begin{array}{l}\text { Water table drawdown occurs symmetrically up to a distance } \\
\text { of } 2.5 \mathrm{~m} \text { around the perimeter of bare peat areas }\end{array}$ & $\begin{array}{l}\text { Flat Tor Pan monitoring } \\
\text { data, University of Exeter }\end{array}$ \\
\hline
\end{tabular}


Field validation

To quantify the spatial accuracy of the digitised (mapped) features and to confirm the correct identification of features, a number of each feature type (drains, cuttings and gullies) were selected for investigation in the field for ground-truthing. Features were selected from the GIS mapping and X, Y coordinates loaded into a handheld global positioning system (GPS) receiver (Garmin International, Olathe, KS, USA). The GPS was used to navigate to the selected validation features. At each feature, a visual check was made to confirm the interpretation of the feature (i.e. that a map feature attributed to a peat cutting, was in fact a cutting). A field survey using a Leica Viva GS08plus GNSS (Global Navigation Satellite System) (with a spatial accuracy of approx. $2 \mathrm{~cm}$ ) was then undertaken to record the selected feature. For linear features, such as drainage ditches, coordinates of the start, mid- and end points of the feature were collected. The location $(\mathrm{X}, \mathrm{Y})$ and length $(\mathrm{m})$ of the feature as collected by data points in the real world validation were then compared to the location and length of the corresponding feature that had been mapped (during on-screen digitising). In the case of polygonal features, such as peat cuttings and bare/sparsely vegetated peat areas, the edges were walked during field survey and data points recorded at regular intervals (with higher sampling frequency around corners to ensure sufficient detail was collected). To validate the accuracy of the interpretation and on-screen featuredigitising, the total area $\left(\mathrm{m}^{2}\right)$ of the corresponding feature surveyed in the field was compared to the mapped feature. The percentage of ground validation data that had been captured as the same feature type in the digitised data was then calculated.

\section{Results}

An integrated approach to quantify features over the whole landscape using multiple datasets

The integration of high resolution LiDAR datasets and CASI imagery, assisted by the viewing of aerial photography datasets, allowed for the identification of the location and extent of peatland degradation features across the whole extent of Dartmoor (Fig. 3a, Table 2). Through the process of interpretation and mapping of features a comprehensive dataset, with a good level of accuracy (Table 3), was produced. An extended analysis of the resultant attribute data allowed extraction of a subset of each feature type to which appropriate buffers were applied (Fig. 4, Table 2) which contributes to the understanding of drivers of ecohydrological change across the Dartmoor peatland area.

\section{Drainage ditches}

Drainage ditches were well resolved and easily identifiable as linear depressions in the de-trended LiDAR DSM and aerial imagery. The quality and degree of detail captured in the LiDAR data (Fig. 3c) revealed the extent of drainage features across this peatland landscape (Table 2) and facilitated the ability to differentiate linear drainage features from such features as vehicle tracks, fences and other landscape features. A digitised dataset of anthropogenic drainage ditch features was therefore extracted and features quantified.

In total 4690 drainage ditch features were digitised across the whole moorland extent. This represented a total length of $426.7 \mathrm{~km}$ of anthropogenic, linear drainage (Table 2). In some cases, where extensive peat cutting had taken place, the definition of the drainage ditches had been lost with the removal of the surrounding peat. This resulted in the occasional discontinuous linear feature in the LiDAR image data. As only visible drains were digitized, this figure could be an underestimation of the true area of peat that has been impacted by anthropogenic drainage.

Using the assumption that drains had an internal width of $0.5 \mathrm{~m}$ (Armstrong et al. 2009) and following application of the appropriate buffers to the relevant drain features (see "Methods" Section), the total extent of peatland area identified as ecohydrologically affected by drainage ditches was $2.4 \mathrm{~km}^{2}$ (Table 2).

Drainage ditches were locally dense or concentrated around areas historically used for peat cutting (Fig. 3a) and were therefore focussed around the deep peat areas of Dartmoor (Fig. 1). Consequently $1.4 \%$ of the deep peat areas $(>40 \mathrm{~cm})$ (Fig. 1) were found to be ecohydrologically affected by drainage ditches (Table 2). 


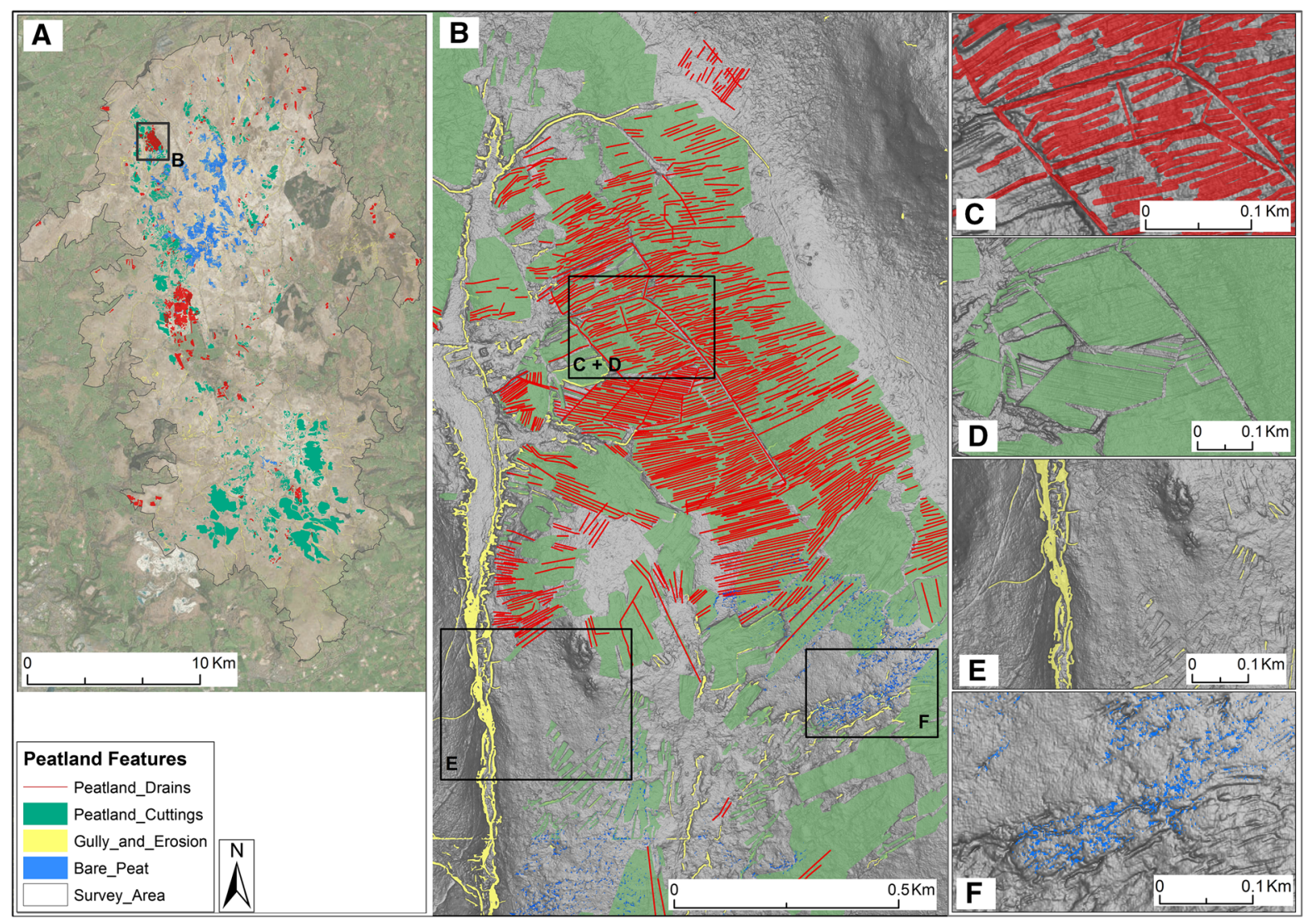

Fig. 3 a Overview of the study area illustrating the extent of mapped features overlying a true colour image, black box B locates panel B. b Hillshade extent of LIDAR DSM demonstrating how features relate to each other within the landscape, black boxes C-F locating Panels C, D, E and F. Illustration of

\section{Peat cuttings}

Visual analysis of the remotely sensed data also allowed for identification of historical peat cuttings at a fine spatial scale (Fig. 3d). At the resolution of the data available to this study ( $1 \mathrm{~m}$ LiDAR, $0.125 \mathrm{~m}$ aerial photography) even discontinuous and overgrown or revegetated peat cuttings were identifiable, appearing as topographic depressions. However, the depth and morphology of the cutting feature (in the real world) influenced whether or not the edges of the features were clearly visible in the LiDAR DSM.

Often the original straight sides of the peat cutting had eroded and revegetated or back-filled. In these cases interpretation was required for one or more sides of the cutting to enable it to be digitized as a closed polygon feature. Furthermore, in some areas where the detail possible when mapping c linear drainage (red features), d peat cuttings (green features), e erosional gullies (yellow features) and $\mathbf{f}$ bare peat (blue features) using high resolution remote sensing datasets. (Color figure online)

industrial scale peat-cutting had occurred, or such a high density of peat extraction that individual cuttings had merged and become indistinct, the interfaces between cut and intact areas of peatland had to be interpreted. Accordingly, the perimeter of the wider area affected by cutting was digitised as a single large polygon (Fig. 3d).

Across the entire study area, 5250 features inferred to be peat cuttings were visually identified (Fig. 3a) and digitised, covering a spatial extent of $26.6 \mathrm{~km}^{2}$ (Table 2).

The subset of cutting features used to assess the wider ecohydrological impact (distinct, well-defined cuttings), accounted for $5.6 \mathrm{~km}^{2}$ which increased to $8.0 \mathrm{~km}^{2}$ with a $3 \mathrm{~m}$ buffer applied. This represents $4.6 \%$ of the Dartmoor deep peat area (Table 2). 
Table 2 Summary table showing: total area of each feature type mapped (before buffers applied) $\left(\mathrm{km}^{2}\right)$

\begin{tabular}{lllll}
\hline Feature & $\begin{array}{l}\text { Total area of mapped } \\
\text { features }\left(\mathrm{km}^{2}\right)\end{array}$ & $\begin{array}{l}\text { Area of subset of } \\
\text { features }\left(\mathrm{km}^{2}\right)\end{array}$ & $\begin{array}{l}\text { Estimated ecohydrologically } \\
\text { affected area }\left(\mathrm{km}^{2}\right)\end{array}$ & $\begin{array}{l}\text { \% of Dartmoor deep peat } \\
\text { area }(>40 \mathrm{~cm})\end{array}$ \\
\hline $\begin{array}{l}\text { Erosion and } \\
\text { gully }\end{array}$ & 7.9 & $4.4^{\mathrm{a}}$ & 12.6 & 7.2 \\
$\begin{array}{l}\text { Peat cutting } \\
\begin{array}{l}\text { Drainage } \\
\text { ditch }\end{array}\end{array}$ & 26.6 & $5.6^{\mathrm{a}}$ & 8.0 & 4.6 \\
$\begin{array}{l}\text { Bare peat } \\
\text { Bare }\end{array}$ & 0.9 & 0.2 & 2.4 & 1.4 \\
\end{tabular}

The total area of each subset of feature type (before buffers applied) $\left(\mathrm{km}^{2}\right)$ and the total ecohydrologically affected areas of those subsets of features (with buffers applied) $\left(\mathrm{km}^{2}\right)$. Finally, area of ecohydrological impact of each feature type presented as a percentage of the Dartmoor deep peat extent ( $>40 \mathrm{~cm}$ peat depth) (Gatis et al. 2019)

${ }^{a}$ Estimation of the ecohydrologically affected area was done through the application of buffers to features understood to actively influence the ecohydrology of the surrounding peat. The subset of features selected for buffering included: Erosion and gully features identified as having medium or high flow and Peat cuttings identified as distinct, well-defined. Other features (e.g. indistinct cuttings, over-cut extents and gully type features with low flow accumulation) were not included in this estimate as they lack empiric evidence of active ecohydrologic influence. However, these features were still supplied to the end users as a complete record of the mapped landforms

Table 3 Summary of dataset accuracy

\begin{tabular}{llll}
\hline Mapped feature & Ground data (field validation) & Classification data (digitised data) & $\%$ Accuracy \\
\hline Peat drains & $2228.4 \mathrm{~m}$ & $2098.6 \mathrm{~m}$ & 94 \\
Peat cuttings & $8394.8 \mathrm{~m}^{2}$ & $7291.5 \mathrm{~m}^{2}$ & 87 \\
Gully and erosion & $896.5 \mathrm{~m}$ & $623.0 \mathrm{~m}$ & 70 \\
Bare peat & $897.1 \mathrm{~m}^{2}$ & $600.7 \mathrm{~m}^{2}$ & 67
\end{tabular}

Mapped data were compared to ground validation data from field survey using a differential GPS

Mapping peat cuttings confirmed the areas of known historical, commercial peat cutting (e.g. Rattlebrook Hill, Walkham Head and Blackbrook Head), which are located in areas of known deep peat running north to south on the western side of the study area and an area of the south Moor (Brent Moor) (Figs. 1 and 4a).

Occurrence and location of erosional gullies

Analysis of the data produced from the de-trended LiDAR imagery allowed the extraction of topographic depressions consistent with erosional peatland gullies. These features were mapped throughout the landscape (Fig. 3a) and included incised features representing erosional and both vegetated and un-vegetated gully features (Fig. 3e).

The resultant dataset included over 50,000 features (Fig. 3a) representing a total mapped area of ca.
$7.9 \mathrm{~km}^{2}$ (Table 2). Of this, a subset of $4.4 \mathrm{~km}^{2}$ (active gullies classified as having "medium" and "high" flow) were identified. With buffers applied the total area ecohydrologically affected by medium and high flow erosional gully features totalled $12.6 \mathrm{~km}^{2}$ or $7.2 \%$ of the Dartmoor peatland extent.

The erosion and gully features were distributed relatively evenly across the study area, although the greatest concentration of features was noted to be in the central, north section of the study area, the location of highest elevations on Dartmoor and coincident with the deep peat areas (Fig. 1. Gatis et al. 2019).

Bare peat

Identification and mapping of bare peat areas showed that these features are complex in shape and form (Fig. 3f). The resultant dataset illustrated that they are largely limited to the northern central portion of the 

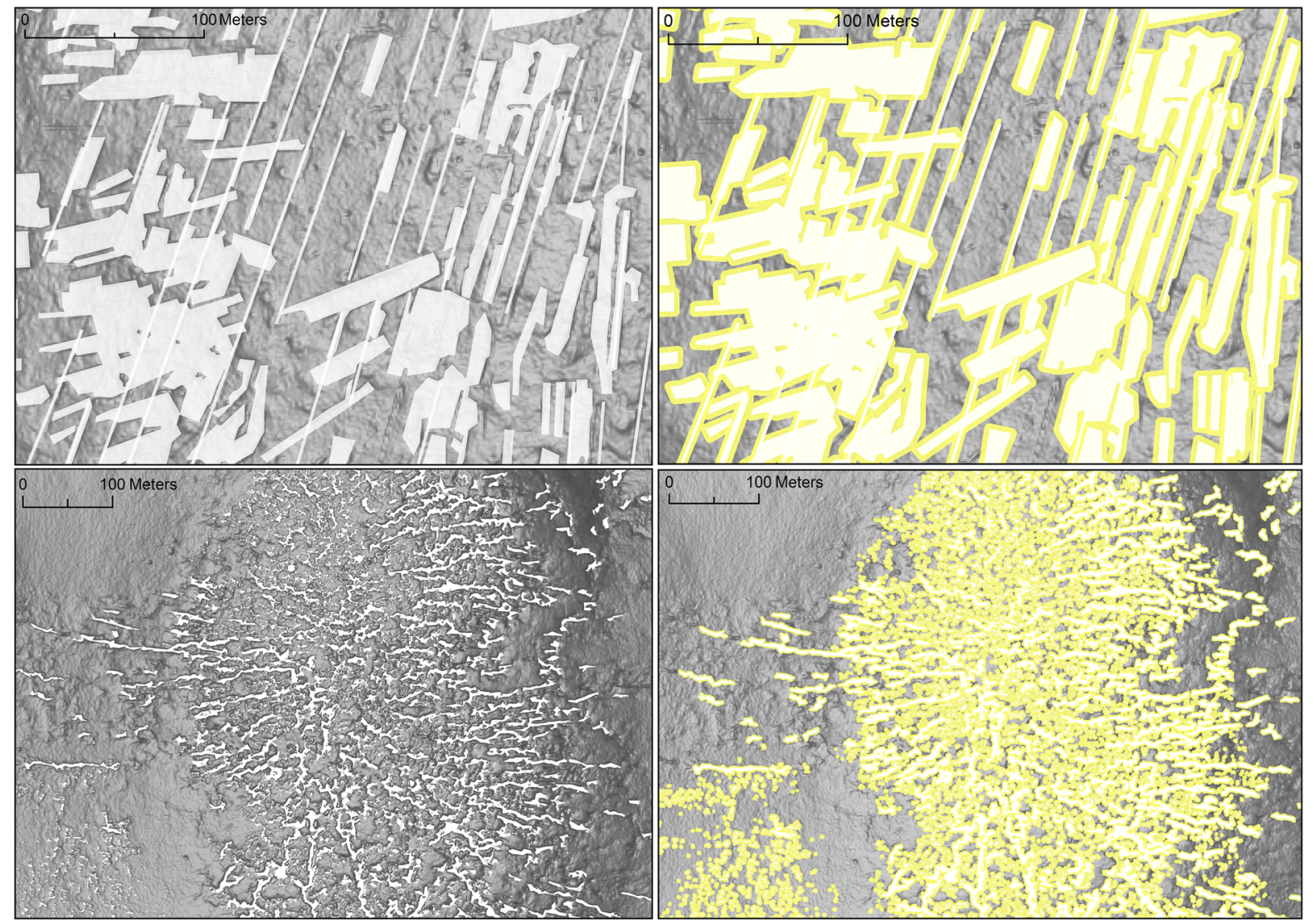

Fig. 4 Examples of mapped features (left hand side) including peat cuttings and drainage ditch features (upper image) and bare peat areas and gully features (lower image) and the same features with buffers applied, represented in yellow (right hand side)

study area (Fig. 3a), coincident with the gully and erosion features (Fig. 3f) and deep peat areas (Gatis et al. 2019). They also occurred predominantly on flatter (and convex) portions of the landscape surface, where bare peat pans are known to form (Gatis et al. 2019).

In total, the analysis identified and mapped $0.9 \mathrm{~km}^{2}$ of bare peat (Table 2). $2.5 \mathrm{~m}$ buffers were applied to bare peat areas to provide an estimate of ecohydrological impact. In total $6 \mathrm{~km}^{2}$ or $3.4 \%$ of the Dartmoor peatland area ( $>40 \mathrm{~cm}$ peat) has been ecohydrologically affected by the development of bare peat areas.

\section{Validation and uncertainties}

The primary sources of data for this study were the Tellus LIDAR and aerial image datasets. As with any study using these types of data it is necessary to acknowledge and consider appropriately the inherent sources of uncertainty (spatial uncertainty and that introduced by processing) in all data used and in the interpretation and surveying of features during ground truthing (decision making when identifying and recording boundaries of features).

The positional accuracy of any subsequent derived dataset (e.g. digitised polygon shapefiles/layers) depends on the spatial accuracy of the raw data used (i.e. the DSM/topographic data), in addition to the accuracy and precision employed by the user tasked with identifying and digitising features.

The main aim of this study was to test methods for quantifying key features and measuring the spatial extent of ecohydrological impact of those features including; 1 . Anthropogenic drainage ditches and peat cuttings, 2. Erosional gullies and 3. Bare peat areas and to facilitate understanding of how they interact in the landscape in order to inform management and potential future restoration activities. It was therefore 
important to validate both the qualitative (interpretation and labelling of feature type) and quantitative (X, $\mathrm{Y}$ location and extent) accuracy of the derived datasets.

The results of the validation exercise (Table 3), show that drainage feature mapping presented the greatest accuracy, $94 \%$ of features mapped in the field were also identified and mapped in the LiDAR dataset. The anthropogenic peat cuttings achieved good agreement between ground data and digitised data. When compared, $87 \%$ of the area mapped in the field were also found to have been mapped from the LiDAR dataset during the digitising exercise. However, it was noted that peat cuttings can be complex features and often a clear, hard line does not exist in the field with peat slumps and clumps of vegetation making edges hard to define. Therefore, some uncertainty still exists in defining the extents of the features both in the field and in the LiDAR data. This also applied to areas of bare peat. Even so, $67 \%$ of the digitised bare peat areas were confirmed to have been mapped accurately from the LiDAR dataset when compared to a reference dataset. Finally, the GPS points collected along gully edges mapped well onto the Lidar derived gully mapping with an accuracy of $70 \%$.

\section{Discussion}

GIS and RS image analysis as a method for mapping peatland features

Consistent with other Northern peatlands (e.g. Nordic and Baltic regions, Northern Ireland, Caithness and Sutherland-Scotland, Pennines-Northern England, Migneint-Arenig-Dduallt and the Berwyn \& South Clwyd Mountains-Wales) (Stewart and Lance 1991; Holden et al. 2004, 2006; Evans et al. 2005; Ramchunder et al. 2009; Wilson et al. 2011; Bellamy et al. 2012; Joosten 2015), Dartmoor exhibits extensive, dense drainage networks and peat cuttings across its blanket peatland area and subsequent ecohydrological degradation, including erosional gullies and areas of bare peat (Fig. 3).

For appropriate and effective management of peatland landscapes, including monitoring of rates of change due to restoration, it is important to know the location and extent of degradation features within the wider landscape. The workflow presented here
(Fig. 2) demonstrates, for the first time, that both anthropogenic and natural disturbance features contributing to the ecohydrological degradation of blanket bog can be identified and quantified at the landscapescale from remotely sensed datasets (Fig. 3). Where often these features are considered in isolation or as small groups of features within a specific, single site, here we demonstrate the ability and the importance of viewing them in combination, at the landscape-scale (Fig. 3b), for the evaluation of peatland condition and assessment of their impact on peatland functioning. Furthermore, as previously discussed by Connolly et al. (2007), Krankina et al. (2008), DabrowskaZielinska et al. (2009) and Aitkenhead (2017), combining multiple datasets has been shown here to be of greater use and produce more accurate mapping than the use of a single dataset (for example aerial photographs).

Identifying and quantifying features in support of peatland restoration

This study integrated manual and automated feature extraction from remotely sensed data (LiDAR, CASI) and aerial image data, with ground-based validation data, allowing for greater visualisation and understanding of the landscape as a whole.

We demonstrated that anthropogenic features (peat cuttings and drains) are clearly visible in the fine resolution LiDAR imagery available (Fig. 3c, d). A workflow was developed to identify and manually digitise the features in a GIS (Fig. 2). This has resulted in a robust estimate (Table 3) of many kilometres of drainage ditches across Dartmoor and the area of blanket bog that has been affected by peat cutting activity (Table 2). Our findings illustrate that linear features tended to exhibit the largest potential to accumulate flow (Holden et al. 2004). This is important for management as these features may be the most hydrologically active and simplest to block, and may therefore deliver significant hydrological benefits if restored.

In addition, automated classifications combined with visual checks and manual cleaning were used in this study to accurately identify erosional gullies and bare peat areas (Table 3), allowing their quantification (Table 2) but furthermore, visualisation of the potential associations between these features (Fig. 3b). 
Viewing the erosional gully and bare peat features at the landscape-scale and with the ability to display them with other mapped features, demonstrated that a significant proportion of the gully and erosion features were immediately proximal to the bare peat areas that were also mapped (Fig. 3), further facilitating management decisions and prioritisation of restoration, which could focus on stabilising erosion features, followed by revegetation of bare peat (Evans et al. 2005; Armstrong et al. 2009; Parry et al. 2014a).

LiDAR and aerial imagery has the advantage of revealing features not necessarily visible in the field. For example, numerous large relict peat cutting areas were mapped within the three known (historical) commercial peat cutting areas of Dartmoor (as discussed in Newman (2010)). In addition, a number of smaller areas of peat cutting were also identified. These are visible in the LiDAR data as dark rectangular blocks, but are often not obvious in the field due to the height of vegetation and could therefore be missed in a visual or walkover assessment. This type of feature mapping is important to gain an understanding of the full scale of disturbance that the peatland area has experienced and to facilitate consideration of all types of disturbance (including historic) for management and planning purposes.

The spatial distribution of peat cutting activity and associated drains also illustrated that these features correspond well with areas of deep peat identified in other studies (Gatis et al. 2019) (Figs. 1 and 3a)areas important for conservation. The identification and mapping of erosional gullies, including relict and active, vegetated and unvegetated features in combination with flow accumulation modelling, highlighted features which may be most vulnerable to future soil erosion episodes (Fig. 3a, e). As peatlands are wetland systems, identifying actively eroding and hydrologically connected gullies is often a key priority for peatland conservation and restoration, providing a means to tackle the main paths of water loss/discharge efficiently and sources of sediment/peat export from these sites (Evans et al. 2005; Armstrong et al. 2009; Labadz et al. 2010; Lunt et al. 2010; Shepherd et al. 2013; Thom et al. 2016). Such restoration can reduce the loss of peat and its associated impact downstream on drinking water (quality) and the wider degradation in ecosystem services (carbon storage, biodiversity, water storage), as well as ensuring that restoration efforts are most resilient where water erosion is most prevalent.

The combined use of classified CASI, $2 \mathrm{~m}^{2}$ resolution data and de-trended LiDAR data at $1 \mathrm{~m}^{2}$ resolution allowed bare peat "pans" to be identified and successfully mapped (Fig. 3, Table 2) and were confirmed by field validation (Table 3 ). Again the results showed that the methods were successful in identifying the location and extent of these features.

Using knowledge from other studies (Holden et al. 2006; Labadz et al. 2010) buffers, of a specified distance were applied to features (Table 1). This extended the feature to provide a more realistic extent of ecohydrological impact of both drains and gullies on the ecohydrology of the study area. This is critical information for informing restoration activities and for accounting for carbon and water loss from sites (current or potential).

This workflow could be replicated across degraded peatlands more widely, assuming that LiDAR and aerial image data are available and therefore may meet the needs of individuals and organisations including Bain et al. (2011), Natural England (2011), the Joint Nature Conservation Committee (JNCC) (2011) and the International Union for Conservation of Nature (IUCN) (Lunt et al. 2010) to investigate the rich source of information available in remotely sensed data in order to develop efficient and robust methods for landscape-scale mapping of peatland features, including degradation.

\section{Lessons learned}

During the interpretation and digitising exercise, caution was required to evaluate features, having also to consider characteristics such as shape, size and position within the landscape to ensure logical interpretations of less distinct features. The unique combination of LiDAR data processing, combined with fine resolution aerial photography data (allowing visual evaluation) made this level of digitisation detail possible.

Whilst validation was limited due to financial and temporal constraints, there was good agreement between real world validation data and the digitised (mapped) data (Table 3). For complex features such as erosional gullies, manual digitising appears to perform close to, or better than, automated feature detection (unless very high resolution data is available). For 
example, the agreement between the digitised data and validation data sets for gully and erosion features in this study was $70 \%$. However, automatically extracted features (bare peat areas and gully features) are also far more numerous than those manually mapped, and as such manual digitisation would not always be a viable alternative.

Furthermore, whilst visual identification and manual digitising of features over such a large area is time consuming, it is more rapid than field-mapping especially considering the great number of features present, the level of detail required, the difficult terrain in sometimes extreme environments and landscapescale nature of the work.

Further work: identifying candidate sites for restoration/prediction of vulnerable areas

This study provides essential information and mapping for prioritisation of restoration and stabilisation of bare peat which has been shown to be a critical goal in peatland management (Moors for the Future Partnership 2013; Lindsay et al. 2014; Parry et al. 2014b). The integration of spectral and structural remote sensing data used in this study may also allow the identification of good condition/functionally intact peatland extents that are adjacent to damaged, eroded or gullied areas, and which are therefore vulnerable and at risk of degrading.

Knowing the extent and location of these areas is necessary for the continued monitoring and management of vulnerable areas and for identification of candidate sites to be prioritised for restoration and management works. Targeting restoration activity in areas of active gullies and drains as a result of this work could be an effective way to optimise the number and location of peat blocks required for rewetting a specific area. For example, Evans et al. (2005) report an approach that was developed to allow high resolution topographic data based on LiDAR to be coupled with hydrological predictions about hillslope saturation. Evans et al. (2005) illustrated that a spatially explicit hydrologic decision making tool for choosing strategic locations for gully blocking in deep peat was useful and we argue that the research presented herein, which would allow the landscapescale identification of where active erosion gullies were, would be highly complementary to such a modelling approach. In addition, such strategic, spatially explicit planning of restoration could ensure that resources and finances are focussed in areas where rapid reduction of water loss can be achieved, raising water levels and eventually encouraging re-vegetation and stabilisation and protection of denuded or vulnerable areas.

\section{Conclusions}

For the first-time, fine spatial resolution $(1 \mathrm{~m})$ and landscape-scale mapping $\left(35.6 \mathrm{~km}^{2}\right)$ of anthropogenic and natural erosion features has been produced for Dartmoor, a climatically-marginal peatland in the south-west UK. This mapping can now underpin future management strategies that seek to conserve the peat resource.

Using fine-scale, large-extent remotely sensed data (LiDAR, CASI) combined with aerial imagery enabled key features (linear drainage ditches, erosional gullies, peat cuttings and bare peat), within the wider extent of peatland to be identified successfully and mapped at a resolution appropriate to future targeted restoration of this landscape. In addition, the overall areas of functionally degraded peatland were estimated (following buffering of selected key features), demonstrating that an area of approximately $29 \mathrm{~km}^{2}$ or $9.2 \%$ of the Dartmoor peatland area is significantly and directly ecohydrologically degraded. The study clearly shows the advantages of using remotely sensed and aerial data over traditional ground survey methods, which are time consuming and costly given the remote locations and large extent of the landscape that has been analysed.

Acknowledgements The authors would like to thank Dartmoor National Park Authority [Grant No. SK07279], Dartmoor Peatland Partnership, the Duchy of Cornwall, Environment Agency, Forestry Commission, the Ministry of Defence, Natural England, the South West partnership for Environmental and Economic Prosperity (SWEEP) and South West Water [Grant No. SK06855], who commissioned, funded and/or supported the project. SWEEP was funded by the Natural Environment Research Council (Grant No. NE/P011217/1).

Open Access This article is distributed under the terms of the Creative Commons Attribution 4.0 International License (http:// creativecommons.org/licenses/by/4.0/), which permits unrestricted use, distribution, and reproduction in any medium, provided you give appropriate credit to the original author(s) and the source, provide a link to the Creative Commons license, and indicate if changes were made. 
Funding This work, which was funded by the Dartmoor National Park Authority, the Environment Agency, South West Water and Natural England (and supported by the Dartmoor Peatland Partnership), and is already being used to inform practical management decisions, demonstrates a suite of techniques that are robust, accurate and relatively low-cost for the mapping of similar landscapes, both nationally and internationally.

\section{References}

Aitkenhead MJ (2017) Mapping peat in Scotland with remote sensing and site characteristics. Eur J Soil Sci 68:28-38

Aitkenhead MJ, Poggio L, Donaldson-Selby G, Gimona A, Artz $R$ (2016) Detection of peatland drainage with remote sensing - a scoping study.

Armstrong A, Holden J, Kay P, Foulger M, Gledhill S, Mcdonald AT, Walker A (2009) Drain-blocking techniques on blanket peat: A framework for best practice. J Environ Manag 90:3512-3519

Bain CG, Bonn A, Stoneman R, Chapman S, Coupar A, Evans M, Gearey B, Howat M, Joosten H, Keenleyside C, Labadz J, Lindsay R, Littlewood N, Lunt P, Miller CJ, Moxey A, Orr H, Reed M, Smith P, Swales V, Thompson DBA, Thompson PS, Van de Noort R, Wilson JD, Worrall F (2011) IUCN UK Commission of Inquiry on Peatlands

Bellamy PE, Stephen L, Maclean IS, Grant MC (2012) Response of blanket bog vegetation to drain-blocking. Appl Veg Sci 15:129-135

Bonn A, Allott T, Evans M, Joosten H, Stoneman R (2016) Peatland restoration and ecosystem services: nature-based solutions for societal goals. In: Peatland Restoration and Ecosystem Services: Science, Policy and Practice. pp 402-417

Bonnett S, Ross S, Linstead C, Maltby E (2011) A review of techniques for monitoring the success of peatland restoration. Natural England

Bowers K (2015) The effect of peatland restoration on baseflows Exmoor and Dartmoor Mires Project-Environment Agency hydrology report

Burton RG (1987) Lowland peat in England and Wales, soil survey. Soil Survey of England and Wales, Harpenden

Carlsson LM, Bergfur J, Milberg P (2005) Comparison of data from two vegetation monitoring methods in semi-natural grasslands. Environ Monit Assess 100:235-248

Cole B, McMorrow J, Evans M (2013) Empirical modelling of vegetation abundance from airborne hyperspectral data for upland peatland restoration monitoring. Remote Sens 6:716-739

Connolly J, Holden NM (2017) Detecting peatland drains with object based image analysis and Geoeye-1 imagery. Carbon Balance Manag 12:7

Connolly J, Holden NM, Ward SM (2007) Mapping peatlands in Ireland using a rule-based methodology and digital data. Soil Sci Soc Am J 71:492

Dabrowska-Zielinska K, Gruszczynska M, Lewinski S, Hoscilo A, Bojanowski J (2009) Application of remote and in situ information to the management of wetlands in Poland. J Environ Manage 90:2261-2269
Daniels SM, Agnew CT, Allott TEH, Evans MG (2008) Water table variability and runoff generation in an eroded peatland, South Pennines, UK. J Hydrol 361:214-226

Evans M, Allott T, Holden J, Flitcroft C, Bonn A, Brookes C, Crowe S, Hobson G, Hodson S, Irvine B, James T, Liddaman L, Lindop S, Maxfield E, Mchale S, Milner S, Trotter S, Worman C (2005) Understanding Gully Blocking in Deep Peat. Moors for the Future Report 105

Evans M, Lindsay J (2010) High resolution quantification of gully erosion in upland peatlands at the landscape scale. Earth Surf Proc Land 35:876-886

Ferraccioli F, Gerard F, Robinson C, Jordan T, Biszczuk M, Ireland L, Beasley M, Vidamour A, Barker A, Arnold R, Dinn M, Fox A, Howard A (2014) LiDAR based Digital Surface Model (DSM) data for South West England. NERC-Environmental Inf Data Centre. https://doi.org/10. 5285/b81071f2-85b3-4e31-8506-cabe899f989a

Fyfe RM, Coombe R, Davies H, Parry L (2014) The importance of sub-peat carbon storage as shown by data from Dartmoor, UK. Soil Use Manag 30:23-31

Fyfe RM, Greeves T (2010) The date and context of a stone row: Cut Hill, Dartmoor, south-west England. Antiquity 84:55-70

Gallego-Sala A V., Clark JM, House JI, Orr HG, Prentice IC, Smith P, Farewell T, Chapman SJ (2010) Bioclimatic envelope model of climate change impacts on blanket peatland distribution in Great Britain. Clim Res 45:151-162

Gatis N, Luscombe DJ, Carless D, Parry LE, Fyfe RMM, Harrod TR, Brazier RE, Anderson K (2019) Mapping upland peat depth using airborne radiometric and lidar survey data. Geoderma 335:78-87

Gatis N, Luscombe DJ, Grand-Clement E, Hartley IP, Anderson K, Smith D, Brazier RE (2016) The effect of drainage ditches on vegetation diversity and $\mathrm{CO} 2$ fluxes in a Molinia caerulea -dominated peatland. Ecohydrology 9:407-420

Gorham E (1991) Northern peatlands: role in the carbon cycle and probable responses to climatic warming. Ecol Appl 1:182-195

Gorham E, Rochefort L (2003) Peatland restoration: a brief assessment with special reference to sphagnum bogs. Wetl Ecol Manag 11:109-119

Grand-Clement E, Anderson K, Smith D, Luscombe D, Gatis N, Ross M, Brazier RE (2013) Evaluating ecosystem goods and services after restoration of marginal upland peatlands in South-West England. J Appl Ecol 50:324-334

Grand-Clement E, Anderson K, Smith D, Angus M, Luscombe DJ, Gatis N, Bray LS, Brazier RE (2015) New approaches to the restoration of shallow marginal peatlands. J Environ Manage 161:417-430

Haapalehto T, Kotiaho JS, Matilainen R, Tahvanainen T (2014) The effects of long-term drainage and subsequent restoration on water table level and pore water chemistry in boreal peatlands. J Hydrol 519:1493-1505

Haapalehto T, Vasander H, Jauhiainen S, Tahvanainen T, Kotiaho JS (2011) The effects of peatland restoration on water-table depth, elemental concentrations, and vegetation: 10 years of changes. Restor Ecol 19:587-598

Höfle B, Griesbaum L, Forbriger M (2013) GIS-based detection of gullies in terrestrial lidar data of the cerro llamoca peatland (peru). Remote Sens 5:5851-5870 
Holden J, Chapman PJ, Labadz JC (2004) Artificial drainage of peatlands: hydrological and hydrochemical process and wetland restoration. Prog Phys Geogr 28:95-123

Holden J, Evans MG, Burt TP, Horton M (2006) Impact of land drainage on peatland hydrology. J Environ Qual 35:1764-1778

Holden J, Walker J, Evans MG, Worrall F, Bonn A (2008) A compendium of UK peat restoration and management projects

Holden J, Wallage ZE, Lane SN, McDonald AT (2011) Water table dynamics in undisturbed, drained and restored blanket peat. J Hydrol 402:103-114

International Peatland Society (2008) Peatlands and climate change. International Peat Society, Jyväskylä

Joosten H (2015) Peatlands, climate change mitigation and biodiversity conservation: an issue brief on the importance of peatlands for carbon and biodiversity conservation and the role of drained peatlands as greenhouse gas emission hotspots. Nordic Council of Ministers, Copenhagen

Joosten H, Clarke D (2002) Wise use of mires and peatlands background and principles including framework for decision-making

Keyworth S, Jarman M, Medcalf K (2009) Assessing the extent and severity of erosion on the upland organic soils of scotland using earth observation. A GIFTSS implementation test 88

Kimmel K, Mander U (2010) Ecosystem services of peatlands: implications for restoration. Prog Phys Geogr 34:491-514

Krankina ON, Pflugmacher D, Friedl M, Cohen WB, Nelson P, Baccini A (2008) Meeting the challenge of mapping peatlands with remotely sensed data. Biogeosciences 5:1809-1820

Labadz J, Allott T, Evans M, Butcher D, Billett M, Stainer S, Yallop A, Jones P, Innerdale M, Harmon N, Maher K, Bradbury R, Mount D, Brien HO“, Hart R (2010) Peatland hydrology-draft scientific review. IUCN UK Peatland Programme

Li J, Chen W (2005) A rule-based method for mapping Canada's wetlands using optical, radar and DEM data. Int J Remote Sens 26:5051-5069

Li C, Grayson R, Holden J, Li P (2018) Erosion in peatlands: recent research progress and future directions. Earth Sci Rev 185:870-886

Lindsay R (2010) Peatbogs and carbon. A critical synthesis to inform policy development in oceanic peat bog conservation and restoration in the context of climate change. RSPB (Scotland)

Lindsay R, Birnie R, Clough J (2014) IUCN UK Committee Peatland Programme Briefing Note No. 3: Impacts of Artificial Drainage on Peatlands

Littlewood N, Anderson P, Artz R, Bragg O, Lunt P, Land M (2010) Peatland biodiversity. Scientific review. pp 1-35

Lunt P, Allott T, Anderson P, Buckler M, Coupar A, Jones P, Labadz J, Worrall P, Martin E (2010) Peatland restorationIUCN UK peatland programme scientific review

Luscombe DJ, Anderson K, Gatis N, Wetherelt A, Grand-Clement E, Brazier RE (2015a) What does airborne LiDAR really measure in upland ecosystems? Ecohydrology 8:584-594

Luscombe DJ, Anderson K, Gatis N, Grand-Clement E, Brazier RE (2015b) Using airborne thermal imaging data to measure near-surface hydrology in upland ecosystems. Hydrol Process 29:1656-1668

Luscombe DJ, Anderson K, Grand-Clement E, Gatis N, Ashe J, Benaud P, Smith D, Brazier RE (2016) How does drainage alter the hydrology of shallow degraded peatlands across multiple spatial scales? J Hydrol 541:1329-1339

Medcalf KA, Parker JA, Turton N, Bell G (2014) Making Earth Observation Work for UK Biodiversity Conservation. JNCC Report 495 Phase 1167

Mehner H, Cutler M, Fairbairn D, Thompson G (2004) Remote sensing of upland vegetation: the potential of high spatial resolution satellite sensors. Glob Ecol Biogeogr 13:359-369

Milton EJ, Hughes PD, Anderson K, Schulz J, Lindsay R, Kelday SB, Hill CT (2005) Remote sensing of bog surfaces. Joint Nature Conservation Committee, Peterborough, p 366

Minayeva TY, Bragg OM, Sirin AA (2017) Towards ecosystembased restoration of peatland biodiversity. Mires Peat 19:1-36

Moors for the Future Partnership (2013) Moors for the future partnerships restoration methods for restoring bare peat in the South Pennines SAC: evidence-based recommendations

Moxey A, Moran D (2014) UK peatland restoration: some economic arithmetic. Sci Total Environ 484:114-120

Newman P (2010) Domestic and industrial peat cutting on north-western Dartmoor. An Archaeological and Historical Investigation, Devonshire

Parry LE, Charman DJ, Noades JPW (2012) A method for modelling peat depth in blanket peatlands. Soil Use Manag 28:614-624

Parry LE, Holden J, Chapman PJ (2014a) Restoration of blanket peatlands. J Environ Manag 133:193-205

Parry LE, West LJ, Holden J, Chapman PJ (2014b) Evaluating approaches for estimating peat depth. J Geophys Res Biogeosci 119:567-576

Poulin M, Andersen R, Rochefort L (2013) A new approach for tracking vegetation change after restoration: a case study with peatlands. Restor Ecol 21:363-371

Ramchunder SJ, Brown LE, Holden J (2009) Environmental effects of drainage, drain-blocking and prescribed vegetation burning in UK upland peatlands. Prog Phys Geogr 33:49-79

Rochefort L, Isselin-Nondedeu F, Boudreau S, Poulin M (2013) Comparing survey methods for monitoring vegetation change through time in a restored peatland. Wetl Ecol Manag 21:71-85

Rodarmel C, Shan J (2002) Principal component analysis for hyperspectral image classification. Surv Land Inf Syst 62:115-122

Shepherd MJ, Labadz J, Caporn SJ, Crowle A, Goodison R, Rebane M, Waters R (2013) Restoration of degraded blanket bog (NEER003)

Shruthi RBV, Kerle N, Jetten V (2011) Object-based gully feature extraction using high spatial resolution imagery. Geomorphology 134:260-268

South West Water (2014) SWW Water resources management plan 2015-2040 
Stewart AJA, Lance AN (1991) Effects of moor-draining on the hydrology and vegetation of northern pennine blanket bog. Source J Appl Ecol J Appl Ecol 28:1105-1117

Thom T, Evans M, Evans C, Allott T (2016) Blanket mire restoration and its impact on ecosystem services. In: Bonn A, Allott T, Evans M, Joosten H, Stoneman R (eds) Peatland restoration and ecosystem services: science, policy and practice. Cambridge University Press, Cambridge, pp 153-169

Wilson L, Wilson J, Holden J, Johnstone I, Armstrong A, Morris M (2011) The impact of drain blocking on an upland blanket bog during storm and drought events, and the importance of sampling-scale. J Hydrol 404:198-208

Yallop AR, Thacker JI, Thomas G, Stephens M, Clutterbuck B, Brewer T, Sannier CAD (2006) The extent and intensity of management burning in the English uplands. J Appl Ecol 43:1138-1148

Publisher's Note Springer Nature remains neutral with regard to jurisdictional claims in published maps and institutional affiliations. 